\title{
Pengelolaan Dana Desa Di Tinjau Dari Perspektif Pencegahan Korupsi
}

\author{
Shela Delvia Hans, Rustam Hs Akili, Roy Marthen Moonti, Yusrianto Kadir, \\ Ibrahim Ahmad \\ Fakultas Hukum Universitas Gorontalo \\ shelladelvia1311@gmail.com,akilirustam@gmail.com,roymoonti16@gmail.com, \\ yusrikadir@gmail.com,ibrahimahmad.ug@gmail.com
}

\begin{abstract}
The research aims at investigating the prevention efforts of corruption crime of management village fund reviewed from Indonesian law and to investigate the village fund management model reviewed from the perspective of corruption prevention aspect. This research used normativeempirical, the data used primary and secondary data from questionnaires and interview.

This research is analyzed in qualitative with inductive method, and descriptive which is explaining, and describe appropriate with problems related with this research. In prevent corruption happens in management village fund, the effort which is offered by the researcher is: identified corruption modus, the increase ofintegrity capacityvillage officials, increase the capacity of village facilitators, refused intervention from local government in order to prevent the fraud in managing village funds and model village funds management of all village refers to Minister of Home Affairs regulation number 20 year of 2018 changes to the Minister of Home Affairs regulation number 113 year of 2014 which clearly there are all governance of village fund management models that are right on target, but in managing the village fund is still has officials not maximum or patient in manage village fund.Suggestion which is offered from the researcher in prevent corruption are identifycorruption modus, the increase ofintegrity capacity village officials, increase the capacity of village facilitators, refused intervention from local government, and $T$ test result showed that the efforts of corruption prevention is effective and influence in management of village fund.
\end{abstract}

Keywords: Management, Village Fund, Corruption Prevention.

\section{PENDAHULUAN}

Korupsi merupakan perbuatan yang jahat yang setiap tahunnya meningkat baik secara kualitas dan kuantitasnya. Tindak pidana korupsi yang jumlahnya makin meningkat akan berdampak buruk terhadap kesejahteraan hidup masyarakat. Sedangkan Negara memiliki 
tanggungjawab untuk meningkatkan kesejahteraan hidup masyarakat. Dampak korupsi yang demikian besar merupakan masalah serius yang berpengaruh terhadap kesejahteraan hidup masyarakat, ini merupakan tanggung jawab dari seluruh unsur masyarakat dan stack holder sebab masalah korupsi harus di perangi bersama dan di berantas secara bersama-sama agar kita dapat meminimalisir kejahatan korupsi yang sedang merajalela di Negara Indonesia.

Untuk memerangi korupsi memang bukanlah hal gampang sekalipun melibatkan seluruh unsur masyarakat dan stack holder terkait, sebab tindak pidana korupsi merupakan kejahatan yang di namakan white collar crime yaitu kejahatan yang di lakukan oleh orang-orang yang berkelebihan kekayaan dan mempunyai kekuasaan dan di anggap terhormat dan pelaku tindak pidana korupsi bisa di katakan bukan orang sembarangan karena pelaku korupsi mempunyai akses untuk mempermudah dilakukannya tindak pidana korupsi dengan berbagai macam cara yaitu menyalahgunakan kewenangan melalui kesempatankesempatan yang di milikinya.

Marella Buckley korupsi merupakan penyalahan jabatan publik demi keuntungan pribadi dengan cara suap atau komisi tidak sah. Selaras dengan pendapat di atas, menurut Indriyanto Seno Adji, bahwa tak dapat dipungkiri korupsi merupakan White Collar Crime dengan perbuatan yang selalu mengalami dinamisasi modus operandinya dari segala sisi sehingga dikatakan sebagai invisible Crime yang penanganannya memerlukan kebijakan hukum pidana. ${ }^{1}$

Tindak pidana korupsi diartikan berupa tingkah laku yang menyimpang dari tugas-tugas resmi yang di berikan oleh Negara dan di salah gunakan untuk memperoleh keuntungan secara pribadi,kelompok,ataupun keluarga yang secara langsung merugikan keuangan Negara dan dapat di pidana sesuai dengan undang-undang

\footnotetext{
${ }^{1}$ Ridwan, Upaya Pencegahan Tindak Pidana Korupsi Melalui Peran Serta Masyarakat, Kanun Jurnal Ilmu Hukum, No $6_{4}$ Th. XVI, Desember, 2014 , Hal 1-2.
} 
nomor 20 tahun 2001 tentang pemberantasan tindak pidana korupsi atas perubahan undang-undang nomor 31 tahun 1999.

Agenda reformasi salah satunya yaitu pemberantasan tindak pidana korupsi yang sudah mengakar dan tumbuh subur di Negara Indonesia dan merusak citra dan moral bangsa Indonesia yang belum bisa di tuntaskan secara optimal, berbagai macam upaya yang telah di lakukan oleh pemerintah di masa reformasi sampai orde baru yang belum bisa menghasilkan suatu gagasan kongkrit untuk dapat memberantas korupsi secara merata, bahkan sudah ada lembaga khusus yang di peruntukkan untuk bisa memberantas tindak pidana korupsi namun belum juga maksimal.

Korupsi di era orde baru memang hanya di lakukan oleh segelintir orang yang mempunyai kekuasaan dalam system pemerintahan yang menyalahgunakannya demi keuntungan pribadi, dan dapat di katakan hampir di seluruh aparatur sipil Negara, fakta ini menunjukan bahwa kasus tindak pidana korupsi sudah sangat subur di Negara Indonesia dan susah untuk di berantas dengan berbagai macam upaya, namun kita harus tetap bersama-sama untuk memberantas korupsi yang sudah sangat merusak citra bangsa Indonesia. ${ }^{2}$

Berdasarkan hasil transparency international merilis indeks persepsi korupsi di Negara-negara yang ada di dunia untuk tahun 2017 indonesia berada di peringkat ke 96. Indeks persepsi korupsi tahun 2017 yang terbagi atas 180 negara dirilis pada hari kamis tanggal 22 /2/2018 yaitu transparency internatational menyimpulkan bahwa tidak adanya perkembangan dari setiap Negara-negara yang ada di dunia untuk memerangi dan memberantas tindak pidana korupsi.

Berdasarkan hasil indeks persepsi tindak pidana korupsi ditahun 2017 memperlihatkan bahwa mayoritas Negara-negara yang ada di dunia tidak menunjukan adanya perkembangan ataupun penurunan angka

${ }^{2}$ Fazzan, Korupsi Di Indonesia Dalam Perspektif Hukum Pidana Islam, Jurnal Ilmiah Islam Futura, Vol 14, No.2, Februari, 2015. Hal, 2-3. 
kasus tindak pidana korupsi, dan jika di skalakan bahwa indeks persepsi korupsi dari transparency international menggunakan skala 0-100 yang artinya nilai 0 artinya paling korup, sedangkan nilai 100 artinya paling bersih dan di peringkat terbawah atau dari 180 negara diduduki Somalia dengan nilai 9 negara Indonesia turun 1 poin dari tahun sebelumnya.

Indonesia berada di peringkat ke 96 dengan jumlah nilai 37, selain Indonesia ada beberapa Negara-negara yang ada di dunia yaitu Brasil,kolombia,panama,peru,Thailand,dan Zambia di peringkat dan nilai yang sama. Ini menunjukan bahwa belum adanya peningkatan pemberantasan korupsi dari Negara-negara yang ada di dunia khususnya Indonesia. $^{3}$

Adapun pemberantasan tindak pidana korupsi di Indonesia telah di atur dalam hukum positif yaitu undang-undang nomor 31 tahun 1999 tentang pemberantasan tindak pidana korupsi atas perubahan undangundang nomor 20 tahun 2001, dalam undang-undang tersebut terdapat sanksi pidana yang penerapannya dilakukan secara kumulatif.

Tindak pidana korupsi di Indonesia dari tahun ke tahun semakin meningkat dan sulit untuk di berantas secara maksimal. Tindak pidana korupsi yang semakin meningkat perlu di lakukan peningkatan upaya pencegahan yang tepat sasaran dan strategi pemberantasan yang maksimal untuk memerangi korupsi yang sudah tumbuh subur di Negara Indonesia.salah satu upaya pencegahan tindak pidana korupsi yaitu sanksi hukum yang di jatuhkan bagi pelaku korupsi yang biasa di sebut koruptor merupakan salah satu upaya untuk membuat para pelaku korupsi untuk tidak mengulangi lagi tindak pidana korupsi yang sangat tidak bermoral seperti di jatuhkannya pidana seumur hidup yang tetap

3 Indah mutiara kami, Indeks Persepsi Korupsi 2017 Indonesia Peringkat Ke-96, https://news.detik.com/berita/d-3879592/indeks-persepsi-korupsi-2017-indonesia-peringkat-ke-96. 
tidak memberikan rasa takut atau pun penurunan angka kasus tindak pidana korupsi. ${ }^{4}$

Kasus korupsi yang semakin meningkat setiap tahunnya tanpa pandang bulu membuat begitu banyak kepala desa maupun aparat desa tersandung di dalamnya, dan sejak tahun 2015 pemerintah pusat melalui amanat undang-undang nomor 6 tahun 2014 tentang desa yaitu mengalami kenaikan hingga tahun 2017 dalam hal pengalokasian dana desa, namun di sayangkan di tahun 2018 mengalami beberapa persoalan dalam pengelolaan dana desa mengakibatkan batal naik untuk dana desa di tahun 2018.

Besarnya anggaran untuk desa dengan alokasi dasar masing-masing desa sebesar Rp 616.345 tentulah di harapkan untuk dapat memajukan desa dengan harapan pemerintah berharap peningkatan pelayanan public,masyarakat desa bisa maju dan berdaya, dan yang paling penting desa menjadi subjek pembangunan.akan tetapi yang terjadi adalah dana desa yang kemudian di peruntukan untuk membangun desa dan mensejahterakan masyarakat desa ini malah menjadi lahan korupsi di desa baik yang di lakukan oleh kepala desa ataupun aparat desa setempat.

Indonesia corruption watch melihat bahwa korupsi yang terjadi di desa utamanya yang menyangkut anggaran dana desa,merupakan salah satu problem mendasar yaitu problem ini lahir di karenakan pengelolaan anggaran desa yang besar namun implementasi di tingkat desa tidak di sertai dengan prinsip transparansi,partisipasi,dan akuntabilitas dalam tata kelola pembangunan dalam keuangan desa.adapun berbagai macam bentuk penyalahgunaan anggaran desa dikhawatirkan akan semakin menjadi-jadi di tahun 2018 sebab merupakan tahun konstentasi politik yaitu pilkada serentak di tahun 2018 dan pemilu serentak di tahun 2019. Kekhawatiran ini tidak hanya berangkat dari bacaan terhadap fenomena

\footnotetext{
${ }^{4}$ Margaretha Yesicha Priscyllia, Pemiskinan Koruptor Sebagai Salah Satu Hukuman Alternatif Dalam Tindak Pidana Korupsi, Jurnal, Fakultas Hukum Universitas Atma Jaya Yogyakarta, 2014. Hal,4.
} 
korupsi selama tiga tahun terakhir di desa namun terkait posisi strategis desa dalam konteks pemenangan pemilu, fenomena afiliasi kepala desa dengan calon kepala daerah tertentu,serta minimnya pengetahuan dan pengawasan yang di lakukan oleh masyarakat desa. ${ }^{5}$

Kelonggaran yang di berikan oleh pemerintah pusat kepada pemerintah desa untuk mengelola dana desa yang harusnya membawa banyak manfaat terhadap masyarakat desa terutama dalam pembangunan desa nyatanya di salah gunakan dan tidak di imbangi dengan sadar hukum dalam mengelola dana desa

Adanya pemberian kewenangan atas pengelolaan keuangan desa berdasarkan Permendagri Nomor 20 Tahun 2018 Perubahan atas Permendagri 113 Tahun 2014 Tentang Pengelolaan keuangan Desa memberikan keleluwasaan kepada pemerintah desa untuk mengelola keuangan desa berdasarkan asas pengelolaan keuangan desa yaitu keuangan desa di kelola berdasarkan asas-asas transparan, akuntabel, partisipatif serta di lakukan dengan tertib dan di siplin anggaran. ${ }^{6}$

Korupsi menjadi kejahatan struktural bukan karena a-danya struktur (sistem) sosial yang mengamini, melainkan karena adanya hubungan dualitas (timbal balik) antara struktur dan agen, yang kemudian terikat dan menjerat satu sama lain. Pola Jaringan Korupsi di Tingkat Pemerintah Desa Fenomena ini sangat menarik untuk dikaji, apalagi dalam situasi seperti sekarang ini, dimana adanya indikasi yang mencerminkan ketidakpercayaan rakyat terhadap pemerintah.

Korupsi di Indonesia tidak hanya terjadi dalam tataran pemerintah pusat dan daerah saja, korupsi saat ini mulai masuk kepada lini terkecil pemerintahan lokal. Sektor proyek pembangunan menjadi salah satu langganan koruptor untuk menggerus kekayaan negara, padahal pemerintah pusat begitu sangat optimis untuk melakukan pembangunan

\footnotetext{
${ }^{5}$ Outlook Dana Desa 2018, Potensi Penyalahgunaan Anggaran Desa Di Tahun Politik, Hal 1. https://antikorupsi.org/sites/default/files/outlook_desa_2018_-_icw.pdf

${ }^{6}$ Endah Dwi Winarni, Pertanggungjawaban Pidana Dalam Pengelolaan Dana Desa Berdasarkan PP Nomor 8 Tahun 2016, Jurnal Daulat Hukum, Vol 1, No.1 2018, Hal 272.
} 
di berbagai bidang terutama pembangunan di tingkat desa. Munculnya Dana Desa (DD) menjadi bahan 'empuk' para pemburu rente untuk mengais kekayaan negara. Dengan minimnya pengawasan yang dilakukan pemerintah pusat terhadap desa membuat aliran Dana Desa semakin besar untuk disalahgunakan oleh beberapa oknum pejabat desa dan hanya membuat deretan panjang kasus korupsi yang semakin meningkat dan rakyat semakin menderita, maka apa yang menjadi tujuan dari pengalokasian dana desa untuk mensejahterakan rakyat justru tidak sesuai harapan dan kenyataan.

Di Kabupaten Gorontalo yang menjadi locus penelitian ini, terdapat beberapa perkara korupsi yang pelakunya adalah kepala desa itu sendiri, misalnya di Desa Hutabohu Kecamatan Limboto Barat terdapat korupsi dana desa yang dilakukan oleh Kepala Desa, dan perkara tersebut sudah diputus oleh pengadilan tindak pidana korupsi pada tahun 2018 dengan kerugian Negara sebesar Rp. 150.162.265.00 dan pidana badan 2 tahun 6 bulan Denda 50 juta Subsider 6 bulan biaya perkara 5 ribu uang pengganti 50.162.265.00. Disamping itu, terdapat pula 2 (dua) perkara lagi yang masih dalam penyidikan oleh penyidik tipikor yaitu Kepala Desa Labanu Kecamatan Tibawa dan Kepala Desa Motoduto Kecamatan Boliohuto. Berdasarkan data empiris ini dapat dijelaskan bahwa kehadiran Undang-Undang Nomor 60 Tahun 2014 tentang Keuangan dan Permendagri Nomor 20 Tahun 2018 tentang Pengelolaan Keuangan Desa belum memberikan efek edukasi dan prinsip kehati-hatian kepala desa dalam hal pengelolaan dana desa, konsep yuridis yang telah ada belum cukup membuat para kepala desa atau aparat desa sadar akan pentingnya penggunaan dana desa, sehingga masih banyak terdapat niat jahat (mens rea) yang dilakukan oleh oknum kepala desa.

\section{RUMUSAN MASALAH}


1. Bagaimana upaya pencegahan tindak pidana korupsi dalam pengelolaan dana desa,di tinjau dari peraturan-perundangan Indonesia?

2. Bagaimana model pengelolaan dana desa,apabila di tinjau dari aspek pencegahan tindak pidana korupsi?

\section{METODE PENELITIAN}

Dalam penelitian ini peneliti menggunakan jenis penelitian normatifempiris. Yaitu penelitian berdasarkan studi kepustakaan terhadap aturan hukum dan peneliti membagikan kuisioner kepada kepala desa yang terbagi di 18 kecamatan se kabupaten gorontalo untuk menjadi responden dan juga peneliti melakukan wawancara bersama kepala desa se kabupaten gorontalo.

\section{PEMBAHASAN}

\section{Upaya Pencegahan Tindak Pidana Korupsi Dalam Pengelolaan Dana Desa}

Pemberantasan korupsi telah banyak di lakukan, tetapi harapan untuk menimbulkan efek jera kepada para koruptor masih belum maksimal, hal ini di sebabkan oleh penegakan hukum di Indonesia tidak bebas dari permainan uang dan kekuasaan. Usaha pemberantasan korupsi di Indonesia sedikit demi sedikit bisa memperbaiki citra Indonesia dari berbagai macam tindak pidana korupsi

Korupsi di Indonesia tidak hanya terjadi dalam tataran pemerintah pusat dan daerah saja, korupsi saat ini mulai masuk kepada lini terkecil pemerintahan local yaitu pemerintahan desa. Sektor proyek pembangunan menjadi salah satu langganan koruptor untuk menggerus kekayaan negara, padahal pemerintah pusat begitu sangat optimis untuk melakukan pembangunan di berbagai bidang terutama pembangunan di tingkat desa. Munculnya Dana Desa (DD) menjadi bahan 'empuk' para pemburu rente untuk mengais kekayaan negara. Dengan minimnya pengawasan yang 
dilakukan pemerintah pusat terhadap desa membuat aliran Dana Desa semakin besar untuk disalah gunakan oleh beberapa oknum pejabat desa. ${ }^{7}$

Dana desa yang bertujuan memajukan kesejahteraan masyarakat desa melalui program program di desa kini hanya menimbulkan berbagai macam penyelewengan dana desa yang berakibat terjadinya tindak pidana korupsi dalam pengelolaan dana desa, tentulah tidak sesuai dengan tujuan dari pemerintah pusat untuk dapat menjadikan desa yang mandiri dan sejahtera dalam mengelola rumah tangganya sendiri yang bersumber dari Anggaran pendapatan belanja Negara.

Sementara itu, mengenai Dana Desa, sebagaimana diatur dalam Peraturan Pemerintah No 60 Tahun 2014 tentang Dana Desa yang Bersumber dari Anggaran Pendapatan Belanja Negara (APBN) dan dengan perubahannya yang terakhir berdasarkan Peraturan Pemerintah No 8 Tahun 2016 tentang Perubahan Kedua atas Peraturan Pemerintah No 60 Tahun 2014 tentang Dana Desa yang Bersumber dari Anggaran Pendapatan dan Belanja Negara, Pasal 1 Ayat (2) menyebutkan; Dana Desa adalah dana yang bersumber dari APBN yang diperuntukkan bagi desa yang ditransfer melalui Anggaran Pendapatan dan Belanja Daerah (APBD) Kabupaten/Kota dan digunakan untuk membiayai penyelenggaraan pemerintah, pelaksanaan pembangunan, pembinaan kemasyarakatan ,dan pemberdayaan masyarakat. Selanjutnya Pasal 6 disebutkan bahwa Dana Desa tersebut ditransfer melalui APBD Kabupaten/Kota untuk selanjutnya ditransfer ke Anggaran Pendapatan dan Belanja Desa (APB) Desa. ${ }^{8}$

Dana Desa sebagai salah satu amanat Undang-Undang No 6 Tahun 2014 tentang Desa yang harus dilakukan oleh pemerintah tak hanya menimbulkan kegembiraan bagi desa yang selama ini terbatas dalam pengelolaan sumber-sumber pendapatan dana desa untuk kemajuan desa,

\footnotetext{
${ }^{7}$ Fathur Rahman, Achmad Baidhowi, Dan Ruth Agnesia Sembiring, Pola Jaringan Korupsi Di Tingkat Pemerintahan Desa, Integritas, Vol.4 , No. 1, Juni 2018. Hal 32

${ }^{8}$ I Made Walesa Putra, I Gusti Agung Ayu Dike Widhiyaastuti, I Putu Rasmadi Arsha Putra, Peran Serta Masyarakat Dalam Pencegahan Tindak Pidana Korupsi Pengelolaan Keuangan Dana Desa, Ilmiah Prodi Magister Kenotariatan 2017-2018, Hal 3.
} 
Tentulah pemerintah pusat sangat mengharapkan Pemerintah Desa dapat berkembang dan menjadikan masyarakat desa yang mandiri dan sejahtera melalui Dana Desa yang di gunakan tepat guna dalam pembangunan dan pemberdayaan masyarakat desa.

Namun harapan dan kenyataan tak sesuai bahkan dalam pemerintahan desa seringkali di dapati penyelewengan pengelolaan dana desa sampai terindikasi sebagai tindak pidana korupsi, tentulah sangat berdampak buruk terhadap cita-cita pemerintah untuk dapat mensejahterakan masyarakat desa.

Melimpahnya sumber daya desa memberikan peluang yang signifikan bagi pemerintah desa dalam membangun perekonomian desa dan kesejahteraan bagi masyarakat desa. Potensi- potensi tersebut harus dilakukan identifikasi secara baik dan dikembangkan melalui pemberdayaan kepada masyarakat secara berkesinambungan. Banyak sekali potensi yang belum tergali secara optimal dan maksimal serta belum dikelola secara baik. Banyak kendala yang melatarbelakangi, antara lain keuangan desa, sumber daya manusia desa dan infrastruktur yang tidak mendukung.

Indonesia corruption watch telah melakukan pemantauan atas korupsi yang terjadi di desa. Hasil pemantauan Indonesia corruption watch, pada tahun 2015 - 2017 kasus tindak pidana korupsi di desa semakin meningkat. Pada tahun 2015, kasus korupsi mencapai 17 kasus dan meningkat menjadi 41 kasus pada tahun 2016. Lonjakan lebih dari dua kali lipat kemudian terjadi pada tahun 2017 dengan 96 kasus. Total kasus korupsi yang ditemukan sebanyak 154 kasus.

Tidak semua dari 154 kasus korupsi di sektor desa di atas merupakan korupsi anggaran desa. Jumlah kasus dengan objek anggaran desa mencapai 127 kasus, sementara turut terdapat 27 kasus dengan objek non-anggaran desa atau total 18\% dari jumlah kasus. Kasus dengan objek non-anggaran desa misalnya pungutan liar yang dilakukan oleh aparat 
desa. Sedangkan objek korupsi anggaran desa mencakup korupsi Alokasi Dana Desa (ADD), Dana Desa, Kas Desa, dan lain-lain.

Kepala desa merupakan aktor yang dominan terjerat kasus. Jumlah kepala desa yang terjerat sebanyak 112 orang. Angka tersebut terus meningkat dari tahun ke tahun, dengan 15 kepala desa pada Tahun 2015, 32 kepala desa pada Tahun 2016, dan 65 kepala desa pada Tahun 2017. Tidak semua pelaku adalah Kepala Desa, pelaku lain adalah 32 perangkat desa dan 3 orang yang merupakan keluarga kepala desa. Yang menarik dari kasus ini adalah KPK turun tangan melakukan OTT karena melibatkan Bupati dan seorang Jaksa. Kemudian dari aspek kerugian negara, korupsi di desa turut menimbulkan kerugian dalam jumlah besar.

Pada tahun 2015 kerugian mencapai Rp 9,12 Milyar. Pada tahun 2016, kerugian mencapai Rp 8,33 milyar. Sementara pada tahun 2017, kerugian melonjak menjadi Rp 30,11 milyar. Total kerugian negara yang ditimbulkan akibat korupsi di sektor desa mencapai Rp 47,56 milyar atau setara dengan alokasi dasar dana APBN untuk 77 desa.

Beragam modus dilakukan oleh para aktor korupsi di desa, di antaranya praktik penyalahgunaan anggaran sebanyak 51 kasus, penggelapan 32 kasus, laporan fiktif dengan 17 kasus, kegiatan/proyek fiktif 15 kasus, dan penggelembungan anggaran sebanyak 14 kasus. ${ }^{9}$

Komisi Pemberantasan Korupsi telah melakukan inventarisir setidaknya 14 potensi permasalahan yang mencakup aspek regulasi dan kelembahaan, tatalaksana, pengawasan dan aspek sumber daya manusia. Lembaga Swadaya Masyarakat Indonesia Corruption watch dalam laporan tahunannya menuliskan teridentifikasi tujuh bentuk korupsi yang umumnya dilakukan pemerintah desa, yaitu penggelapan, penyalahgunaan anggaran, penyalahgunaan wewenang, pungutan liar, mark up, laporan fiktif, pemotongan anggaran dan suap. Tujuh bentuk

\footnotetext{
9 Yusrianto Kadir, Roy Marthen Moonti, Pencegahan Korupsi Dalam Pengelolaan Dana Desa, Ius Kajian Hukum Dan Keadilan, Vol,6 No.3, Desember 2018, Hal 434-436.
} 
korupsi tersebut menunjukkan terdapat lima titik rawan korupsi dalam proses pengelolaan dana desa. Lima titik rawan tersebut adalah pada:

1. Proses perencanaan;

2. Proses pertanggungjawaban;

3. Proses monitoring dan evaluasi;

4. Proses pelaksanaan;

5. Proses pengadaan barang dan jasa dalam hal penyaluran dan pengelolaan dana desa.

Sedangkan modus korupsi dana desa yang berhasil terpantau antara lain:

1. Membuat Rancangan Anggaran Biaya di atas harga pasar.

2. Mempertanggungjawabkan pembiayaaan bangunan fisik dengan dana desa padahal proyek tersebut bersumber dari sumber lain.

3. Meminjam sementara dana desa untuk kepentingan pribadi namun tidak dikembalikan.

4. Pungutan atau Pemotongan dana desa oleh oknum pejabat kecamatan atau kabupaten.

5. Membuat perjalanan dinas fiktif kepala desa atau jajarannya.

6. Pengelembungan (Mark Up) pembayaran honorarium perangkat desa.

7. Pengelembungan (Mark Up) pembayaran Alat tulis kantor.

8. Memungut pajak atau retribusi desa namun hasil pungutan tidak disetorkan ke kas desa atau kantor pajak.

9. Pembelian inventaris kantor dengan dana desa namun diperuntukkan secara pribadi.

10. Pemangkasan anggaran publik kemudian dialokasikan untuk kepentingan perangkat desa.

11. Melakukan permainan (Kongkalingkong) dalam proyek yang didanai dana desa.

12. Membuat kegiatan atau proyek fiktif yang dananya dibebankan dari dana desa. 
Besarnya dana yang harus dikelola oleh pemerintah desa memiliki risiko yang cukup tinggi dalam pengelolaannya, khususnya bagi aparatur pemerintah desa. Fenomena pejabat daerah yang tersangkut kasus hukum jangan sampai terulang kembali dalam skala pemerintahan desa.Aparatur pemerintah desa dan masyarakat desa yang direpresentasikan oleh BPD harus memiliki pemahaman atas peraturan perundang-undangan dan ketentuan lainnya, serta memiliki kemampuan untuk melaksanakan pencatatan, pelaporan dan pertanggung jawaban.Oleh karena itu,sebagaimana diamanatkan dalam UU Desa, pemerintah, pemerintah provinsi, dan pemerintah kabupaten/kota turut membantu memberdayakan masyarakat desa dengan pendampingan dalam perencanaan, pelaksanaan, dan pemantauan pembangunan desa ${ }^{10}$

Berbagai macam penyebab terjadinya korupsi di sector desa, di antara lain di pengaruhi oleh minimnya peranan masyarakat dalam proses perencanaan dan pengawasan dana desa sebagai bentuk pencegahan, tidak efektifnya lembaga-lembaga desa yang berperan seperti badan permusyawaratan desa, intervensi dari pemerintah daerah yang beraviliasi pada kepentingan politik menggunakan dana desa sebagai mahar politik, terbatasnya monitoring dan evaluasi yang di lakukan oleh tim audit di desa, terbatasnya kompetensi perangkat desa yang berakibat terjadinya penyelewengan dalam proses pengelolaan.

Adapun beberapa upaya pencegahan tindak pidana korupsi dalam pengelolaan dana desa yang peneliti tawarkan sesuai dengan hasil penelitian dan kajian yang berdasar pada wawancara bersama 18 kepala desa yang berada di kabupaten gorontalo yang dimana peneliti mendapati berbagai macam permasalahan dan upaya pencegahan korupsi yang peneliti tawarkan antara lain:

a. Mengenali Modus Korupsi

\footnotetext{
${ }^{10}$ Ellectrananda Anugerah Ash-Shidiqq, Hindrawan Wibisono, Akuntabilitas Pengelolaan Dana Desa Sebagai Upaya Pencegahan Korupsi Pengelolaan Dana Desa, Unnes, Vol 4 No,1. 2018, Hal 111-113.
} 
Hingga akhir 2017 lalu sudah hampir 900 kepala desa yang bermasalah dengan hukum karena terjerat kasus tindak pidana korupsi dana desa, sebagian di antara mereka sampai harus menikmati jeruji besi akibat penyalahgunaan dana desa. Jumlah yang begitu banyak di perkirakan akan terus meningkat per tahunnya di karenakan sulitnya mengawasi dan menjangkau dengan teliti 74 ribu lebih desa di seluruh Indonesia. Di sisi lain pola pengawasan yang tidak terjalin oleh masyarakat itu sendiri terhadap pengelolaan dana desa berdampak pada penyalahgunaan dana desa, dan minimnya pemahaman dari perangkat desa dalam menggunakan system pelaporan yang sesuai dengan tata kelola keuangan desa yang mengakibatkan penyalahgunaan dana desa.

Dari jumlah yang di duga begitu banyak bahwa kasus tindak pidana korupsi yang paling banyak terjadi yaitu penyalahgunaan dana desa, Komisi Pemberantasan Korupsi menggarai, modus korupsi dana desa yang sebenarnya memiliki pola yang sama di antara lain : pengadaan barang dan jasa yang tidak sesuai alias fiktif, mark up anggaran, tidak melibatkan masyarakat dalam musyawarah desa dan dalam proses perencanaan pengelolaan dana desa yang tepat guna, dan menggunakan dana desa sebagai kepentingan pribadi dan kelompok, dan lemahnya pengawasan yang di lakukan oleh tim audit mengakibatkan penyalahgunaan dana desa.

Kurung waktu dalam 1 bulan peneliti melakukan penelitian di 18 Desa yang berada di kabupaten gorontalo peneliti mendapatkan beberapa modus tindak pidana korupsi dalam pengelolaan dana desa yaitu :

1. Membuat rancangan anggaran yang tidak sesuai dengan harga pasar, ini dapat di atasi dengan cara dalam proses perencanaan dan pembelian harus di lakukan pengecekan secara langsung di 
pasar ataupun toko-toko terdekat yang akan di jadikan tempat perbelanjaan.

2. Membuat pertanggung jawaban anggaran bangunan fisik yang tidak sesuai dengan jumlah anggaran untuk memperoleh keuntungan secara pribadi maupun kelompok, ini dapat di atasi dengan cara dalam proses pelaporan pertanggung jawaban harus di lakukan menggunakan system transparansi dan akuntabel.

3. Penggelembungan (mark up) pembayaran alat tulis menulis kantor. perbelanjakan dan di sesuaikan dengan alokasi yang di susun.

4. Membuat perjalanan dinas fiktif kepala desa beserta perangkat desa, dalam hal mengikuti kegiatan pembinaan dan pelatihan yang di seleranggakan oleh beberapa instansi terkait dalam hal ini tidak di benarkan, ini dapat di atasi dengan cara pelaporan harus di sertai dengan dokumentasi.

5. Membuat kegiatan atau proyek fiktif yang dananya di bebankan dari dana desa, yang sebenarnya tidak sesuai dengan mata anggaran yang di peruntukan oleh dana desa.

6. Meminjam sementara dana desa untuk kepentingan pribadi dan kelompok dan tidak di kembalikan ke kas desa ini merupakan modus yang seringkali terjadi, di antara lain untuk menanggung biaya hidup yang terlalu banyak.

7. Pungutan atau pemotongan dana desa oleh oknum pejabat kecamatan/kabupaten ini seringkali terjadi dengan berbagai macam alasan dan modus, ini harus di atasi dan di cegah oleh perangkat desa yang tidak boleh takut untuk melaporkan kepada pihak yang berwajib.

8. Penggelembungan (mark up) pembayaran honorarium perangkat desa, modus yang di terapkan ini seharusnya harus di 
laporkan dan tidak boleh terus menerus di lakukan sebab ini merupakan penyalahgunaan dana desa.

9. Melakukan permainan (Kongkalikong) dalam proyek yang di danai dana desa, ini bisa di telurusi sejak di lakukan musyawarah desa dan bisa di gunakan dalam aturan yang di gunakan.

10. Pemangkasan anggaran public kemudian di alokasikan untuk kepentingan perangkat desa, masyarakat harus tahu secara transparansi anggaran dana desa yang di gunakan.

b. Peningkatan Kapasitas Integritas Perangkat Desa

1. Strata Pendidikan Perangkat Desa

Sesuai yang tertuang dalam Undang-Undang Nomor 6 Tahun 2014 Tentang persyaratan menjadi kepala desa Hanya cukup berijazah SMP Dan untuk menjadi perangkat Desa harus berijazah SMA, hal ini tentulah sangat berbanding terbalik dengan kebutuhan. Hal ini sangat berdampak buruk terhadap kapasitas dari perangkat desa itu sendiri, karena strata pendidikan merupakan tolak ukur dalam berbagai macam hal, itu sangat mempengaruhi kewibawaan dan manajemen kepemimpinan seorang kepala desa terhadap perangkat desa, strata pendidikan yang berbeda dan yang di pimpin lebih tinggi derajatnya tentu akan menimbulkan keraguan dari para bawahan untuk mendenge rkan dan mentaati seluruh arahan dari pimpinan, tidak hanya berdasar pada itu pula strata pendidikan sangatlah berpengaruh dalam hal mengeluarkan sebuah kebijakan yang bersifat penting bagi kemajuan desa itu sendiri seringkali kami mendapati para kepala desa hanya menunjuk perwakilan ataupun meminta pandangan kepada para perangkat desa yang seharusnya itu bersifat internal yang akan 
mengukur kemampuan seorang kepala desa dalam memimpin desa.

2. Pendidikan dan pelatihan perangkat desa

Melalui undang-undang Nomor 60 tahun 2014 tentang keuangan desa, di setiap desa di anggarkan dana desa berkisar 1 Milyar Per desa bahkan lebih, tergantung dari banyaknya penduduk yang masih memiliki penghasilan di bawah rata-rata dan berbagai factor lainnya, tentulah membutuhkan pengetahuan dan kapabilitas yang mumpuni dari para perangkat desa itu sendiri, sebab yang akan di kelola dana desa dengan kisaran jumlah yang sangat banyak tentulah tidak semudah yang di bayangkan.

Pendidikan dan pelatihan yang di lakukan oleh pemerintah dan instansi terkait tentulah sangat bermanfaat bagi peningkatan integritas dan kapasitas dari para perangkat desa itu sendiri karena melalui pendidikan dan pelatihan yang rutin di laksanakan ini sangat membantu dari para perangkat desa yang tidak paham dan tidak terlalu mahir dalam pengelolaan dana desa sehingga apa yang menjadi tujuan awal pemerintah pusat untuk meningkatkan kesejahteraan hidup dari masyarakat desa itu sendiri dapat terlaksana.

Selain itu pula pendidikan dan pelatihan perangkat desa ini merupakan kebutuhan dari para perangkat desa itu sendiri karena dengan tingkat pendidikan yang masih di bawah ratarata dan kemampuan dalam mengelola dan memahami tata kelola pengelelolaan dana desa yang tepat guna masih belum terlalu di pahami.

c. Penguatan kapasitas Pendamping Desa

Upaya pencegahan yang dapat di lakukan oleh pendamping desa di antara lain: 
1. Mendampingi desa dalam proses perencanaan, proses pelaksanaan, dan pemantauan terhadap pembangunan yang ada di desa.

2. Melakukan peningkatan kapasitas integritas bagi pemerintah desa, lembaga kemasyarakatan desa dalam hal pembangunan dan pemberdayaan masyarakat desa.

3. Mendampingi desa dalam pembangunan kawasan perdesaan

4. Melakukan pengorganasasian di dalam kelompok-kelompok masyarakat desa.

5. Melakukan peningkatan kapasitas bagi kader pemberdayaan masyarakat desa dan mendorong terciptanya kader-kader pembangunan desa.

6. Mendampingi desa dalam melaksanakan pengelolaan pelayanan social dasar, pengembangan usaha ekonomi desa.

7. Melakukan koordinasi pendampingan di tingkat kecamatan dan memfasilitasi laporan pelaksanaan pendampingan oleh camat kepala pemerintah daerah kabupaten/kota.

d. Menolak intervensi dari pemerintah daerah

Kepala desa selaku penanggung jawab yang mengemban tugas yang cukup berat dalam hal mensejahterakan masyarakat desa dan menjadi panutan di internal perangkat desa tentulah sebagai kepala desa harus memiliki sikap dan moral yang baik dalam menahkodai. Dalam hal mensejahterakan masyarakat desa lewat pemberdayaan masyarakat dan pembangunan sektor desa tentulah tidak lepas dari intervensi ataupun campur tangan dari pemerintah daerah, namun yang harus di ketahui oleh seorang kepala desa dan perangkat desa pemerintah daerah yang memiliki banyaknya kepentingan di masyarakat desa ini bisa menjadi boomerang bagi pemerintah desa dan bisa terjebak dalam tindak pidana korupsi dalam penyalahgunaan dana desa, seperti hal nya dalam kunjungan kerja 
kepala daerah yang demi kepentingan politik ke depan di depan masyarakat menjanjikan kegiatan-kegiatan ataupun pembangunan yang ada di desa yang tidak sesuai dengan program kerja desa selama 6 tahun dan tidak terdapat dalam mata anggaran desa ini akan menjadi boomerang ketika kepala desa tidak berani untuk menolak dan tidak mendengarkan arahan ataupun intervensi dari kepala daerah sebab selaku penguasa daerah tentulah banyak hal dalam bentuk kerjasama bersama pemerintah desa ataupun proyekproyek pembangunan.maka hal yang paling tepat di lakukan oleh kepala desa harus bersikap berani menolak intervensi ataupun campur tangan pemerintah daerah demi terlaksananya pemerintah desa yang bersih dan focus pada kesejahteraan masyarakat desa.

\section{Model pengelolaan dana desa ditinjau dari peraturan perundangan Indonesia}

Alur pengelolaan dana desa berdasar pada undang-undang Nomor 60 tahun 2014 tentang Keuangan Desa maupun Peraturan Menteri Dalam Negeri Nomor 20 tahun 2018 sebagai petunjuk teknis mengenai asas-asas pengelolaan keuangan desa sebagaimana yang di atur dalam tentang pengelolaan keuangan desa dengan tegas menyebutkan, pengelolaan dana desa harus di lakukan dengan empat prinsip utama yakni transparan, akuntabel, partisipatif, dan tertib dan di siplin anggaran.

Dalam peraturan tersebut juga memaknai bahwa pengelolaan keuangan desa mulai dari proses perencanaan, pelaksanaan, penatausahaan, pelaporan, dan pertanggungjawaban. Pengelolaan keuangan desa juga harus di lakukan berdasarkan tata kelola pemerintahan yang baik (Good Govermance). Dan hal yang menjadi perhatian penting dalam good govermance yaitu transparansi dan akuntabilitas. Pemerintah desa tidak akan kuat dan otonomi tidak akan bermanfaat jika tidak di topang dengan hal tersebut. 
Adapun model pengelolaan dana desa yang sesuai dengan permendagri nomor 20 tahun 2018 yang tepat untuk di laksanakan sebagai acuan ialah sebagai berikut :

a. Perencanaan

Proses perencanaan harus di lakukan berdasarkan program, skala prioritas. agenda kegiatan dan terdapat outcome yang jelas dari masing-masing kegiatan. Proses perencanaan pembangunan tertuang dalam rencana kerja pemerintah desa (RKPDesa), RKPDesa ini akan menentukan arah pembangunan desa dalam satu tahun kedepan. Dalam penyusunan RKPDesa ini akan menentukan arah pembangunan desa dalam satu tahun kedepan. Dalam penyusunan RKPDesa ini harus berdasarkan focus perencanaan pemerintah desa yang tertuang dalam rencana pembangunan jangka menengah desa (RPJMDesa). RPJMDesa Dan RKPDesa akan menjadi satu-satunya dokumen perencanaan desa untuk penyusunan APBDesa yang di atur melalui peraturan desa. Selanjutnya di sesuaikan dengan program pembangunan pemerintah kabupaten, pemerintah kota serta dari pemerintah provinsi. Mengingat pentingnya RKPDesa, Di butuhkan peran dari pemerintah desa untuk dapat merancang apa saja yang menjadi prioritas pembangunan setahun kedepan.

b. Pelaksanaan

Pelaksanaan kegiatan-kegiatan yang dananya bersumber dari APBDesa termasuk di dalamnya terdapat dana desa di laksanakan oleh pelaksana teknis pengelolaan keuangan desa (PPKD). Kepala desa selaku pemegang kekuasaan pengelolaan keuangan desa berhak untuk menunjuk siapa saja untuk menjadi PPKD. PPKD sebagaimana di maksud dalam pasal 3 ayat (3) terdiri atas :
a. Sekretaris desa
b. Kaur dan kasi
c. Kaur keuangan 
Dengan adanya PPKD akan membuat manajemen desa terkait dengan efisiensi keuangan desa dalam pernyataan konsep birokrasi “ setiap pejabat berada di bawah pengendalian dan pengawasan suatu system yang di jalankan secara di siplin" dapat di laksanakan dengan baik. Dengan demikian, semua perangkat desa bisa di berdayakan agar program kerja yang telah di rencanakan dapat di laksanakan dengan baik.

Menurut peraturan menteri keuangan Nomor 49 Tahun 2016 mengenai tata cara pengalokasian dana desa. Penyaluran dana desa di lakukan dengan cara pemindahbukuan dari rekening kas umum Negara (RKUN) Ke rekening kas umum daerah (RKUD) untuk selanjutnya di lakukan pemindahbukuan dari RKUD ke Rekening kas desa (RKD). Dalam pelaksanaan keuangan di desa, ada beberapa prinsip yang wajib di taati mengenai penerimaan dan pengeluaran yang di laksanakan melalui RKD.

Seluruh penerimaan dan pengeluaran di desa yang di lakukan oleh pemerintah desa di laksanakan menggunakan RKD, hal tersebut menjadikan system keuangan desa terpusat.

Dalam teori good govermance mengenai strategic vision menjelaskan bahwa kebijakan-kebijakan yang di rumuskan oleh pemerintah desa dan masyarakat harus mengedepankan visi jangka panjang yang di butuhkan untuk pembangunan.

c. Penatausahaan

Penatausahaan keuangan desa di lakukan oleh kaur keuangan sebagai pelaksana fungsi kebendaharaan desa, penatausahaan sebagaimana yang di maksud pada ayat (1) di lakukan dengan mencatat setiap penerimaan dan pengeluaran dalam buku kas umum, pencatatan pada buku kas umum sebagaimana di maksud pada ayat (2) di tutup setiap akhir bulan. 
Di siplin anggaran yang perlu di perhatikan dalam pengelolaan keuangan desa sebagai berikut :

1. Pendapatan yang di rencanakan merupakan hasil dari perkiraan yang objektif sehingga dapat terukur secara rasional, sedangkan belanja yang di anggarkan merupakan batas tertinggi pengeluaran.

2. Pengeluaran harus di dasarkan dengan adanya kepastian tersedianya penerimaan dalam jumlah yang cukup dan tidak di benarkan melaksanakan kegiatan yang belum tersedia dalam APBDes.

3. Penerimaan maupun pengeluaran dalam tahun anggaran harus di masukkan dalam APBDes dan di lakukan dengan rekening kas desa.

d. Pelaporan

Dalam melaksanakan tugas serta kewajibannya dalam pengelolaan keuangan desa, pemerintah desa wajib menyampaikan laporan pelaksanaan APBDesa semester pertama kepada bupati/walikota melalui camat.laporan yang di maksud terdiri dari:

1. laporan pelaksanaan APB desa

2. laporan realisasi

Di samping itu pemerintah desa dalam mempertanggungjawabkan kegiatannya wajib menyampaikan kepada masyarakat.

Pelaporan dana desa sebenarnya tidak terpisahkan dengan penyampaian informasi APBDesa, hanya saja terdapat laporan khusus yang membedakan dengan dana-dana yang lain. Laporan ini bernama realisasi dana desa, laporan realisasi dana desa setiap tahunnya mengalami perubahan terkait dengan ketentuan-ketentuan yang berlaku dalam perundang-undangan

e. Pertanggungjawaban 
Konsekuensi dari penyelenggaraan pemerintah dalam hal pengelolaan dana desa yaitu pertanggungjawaban kepada beberapa pihak yang berkaitan. Dalam hal ini, pemerintah wajib membuat laporan dari pengelolaan dana desa, penyampaian laporan realisasi dana desa secara tertulis, oleh kepala desa ( pemerintah desa ) kepada bupati/walikota.

Dalam tata kelola pemerintahan yang baik (good govermance), maka pertanggungjawaban tidak hanya di sampaikan kepada pemerintah, tetapi juga harus di sampaikan kepada masyarakat.

Dalam model pengelolaan dana desa seluruh desa mengacu pada permendagri nomor 20 tahun 2018 atas perubahan permendagri nomor 113 tahun 2014 yang dimana jelas terdapat seluruh tata kelola model pengelolaan dana desa yang tepat sasaran, namun dalam pengelolaan dana desa masih begitu banyak perangkat desa yang belum maksimal ataupun telaten dalam mengelola sebab kurangnya pengetahuan dari perangkat desa itu sendiri, walaupun upaya dari pemerintah pusat yang sering melakukan sosialisasi ataupun kegiatan pendidikan dan pelatihan di setiap tahunnya namun masih saja kekurangan untuk dapat memantapkan alur pengelolaan dana desa yang tepat sasaran, selain itu pula standar pendidikan dari perangkat desa itu sendiri sangat mempengaruhi kapasitas dan kapabilitas dalam mengelola dana desa yang jumlahnya berkisar 1 Milyar perdesa, tentulah upaya untuk dapat meningkatkan standar pendidikan perlu kembali di perhatikan oleh pemerintah desa tersebut untuk mewajibkan para perangkat desa di sekolahkan, selain itu pula peran serta masyarakat sangat di butuhkan dalam pengelolaan dana desa sebab tujuan pemerintah pusat dengan mengucurkan dana desa yang sangat besar jumlahnya untuk dapat mensejahterakan masyarakat desa maka dari itu perhatian dan fungsi pengawasan perlu untuk di lakukan 
oleh masyarakat desa setempat agar tujuan pengelolan dana desa tidak terjadi tindak pidana korupsi. ${ }^{11}$

\section{PENUTUP}

\section{Kesimpulan}

Adapun yang peneliti temukan tentang upaya pencegahan korupsi dalam pengelolaan dana desa yaitu :

1. Mengenali Modus Korupsi memantapkan fungsi control dari semua elemen yaitu lembaga penegak hukum, Tim audit, Badan Permusyawaratan Desa, Dan masyarakat, Peningkatan Kapasitas Integritas Perangkat Desa dalam hal ini kepala desa dan perangkat desa harusnya bergelar sarjana karena strata pendidikan sangat berpengaruh terhadap kapasitas dan kapabilitas kepala desa, Penguatan Kapasitas Pendamping Desa untuk mencegah terjadinya kongkalikong ataupun kerjasama yang di lakukan oleh kepala desa dan pendamping desa perlu adanya badan pengawasan yang mengawasi alur pendampingan pengelolaan dana desa, Karena locus dari penelitian di kabupaten gorontalo maka di harapkan pada Bupati kabupaten gorontalo untuk dapat melakukan evaluasi kinerja keuangan melalui kepala dinas pemerintahan desa untuk dapat mengoptimalkan pengawasan di desa.

2. Model pengelolaan dana desa,apabila di tinjau dari aspek pencegahan tindak pidana korupsi harus melalui tahapan perencanaan, pelaksanaan, penatausahaan, pelaporan dan pertanggungjawaban.

\section{DAFTAR PUSTAKA}

\section{Jurnal}

Ellectrananda Anugerah Ash-Shidiqq, Hindrawan Wibisono, Akuntabilitas Pengelolaan Dana Desa Sebagai Upaya Pencegahan Korupsi Pengelolaan Dana Desa, Unnes, Vol 4 No,1. 2018.

\footnotetext{
${ }^{11}$ Hasil wawancara bersama kepala desa se kabupaten gorontalo.
} 
Endah Dwi Winarni, Pertanggungjawaban Pidana Dalam Pengelolaan Dana Desa Berdasarkan PP Nomor 8 Tahun 2016, Jurnal Daulat Hukum, Vol 1, No.1 2018.

Fathur Rahman, Achmad Baidhowi, Dan Ruth Agnesia Sembiring, Pola Jaringan Korupsi Di Tingkat Pemerintahan Desa, Integritas, Vol.4 , No. 1, Juni 2018

Fazzan, Korupsi Di Indonesia Dalam Perspektif Hukum Pidana Islam, Jurnal Ilmiah Islam Futura, Vol 14, No.2, Februari, 2015

I Made Walesa Putra, I Gusti Agung Ayu Dike Widhiyaastuti, I Putu Rasmadi Arsha Putra, Peran Serta Masyarakat Dalam Pencegahan Tindak Pidana Korupsi Pengelolaan Keuangan Dana Desa, Ilmiah Prodi Magister Kenotariatan 2017-2018

Margaretha Yesicha Priscyllia, Pemiskinan Koruptor Sebagai Salah Satu Hukuman Alternatif Dalam Tindak Pidana Korupsi, Jurnal, Fakultas Hukum Universitas Atma Jaya Yogyakarta, 2014

Ridwan, Upaya Pencegahan Tindak Pidana Korupsi Melalui Peran Serta Masyarakat, Kanun Jurnal Ilmu Hukum, No $6_{4}$ Th. XVI, Desember, 2014.

Yusrianto Kadir, Roy Marthen Moonti, Pencegahan Korupsi Dalam Pengelolaan Dana Desa, Ius Kajian Hukum Dan Keadilan, Vol,6 No.3, Desember 2018

\section{Sumber Online}

Indah mutiara kami, Indeks Persepsi Korupsi 2017 Indonesia Peringkat Ke96, https://news.detik.com/berita/d-3879592/indekspersepsi-korupsi-2017-indonesia-peringkat-ke-96.

Outlook Dana Desa 2018, Potensi Penyalahgunaan Anggaran Desa Di Tahun Politik, Hal 1. https://antikorupsi.org/sites/default/files/outlook_desa_2018 _-_icw.pdf 
